\title{
Water-Level Changes in the High Plains Aquifer, Predevelopment to 2002, 1980 to 2002, and 2001 to 2002
}

\author{
-By V.L. McGuire
}

The High Plains aquifer underlies one of the major agricultural regions in the world, including parts of eight states-Colorado, Kansas, Nebraska, New Mexico, Oklahoma, South Dakota, Texas, and Wyoming. In the 104.5 million-acre area overlying the High Plains aquifer, not including areas with little or no saturated thickness (fig. 1), the total number of acres irrigated with ground water increased rapidly after 1940 . Irrigated acres comprised 2.0 percent of the aquifer area in 1949, 13.1 percent in 1980, and 13.3 percent in 1997-(Heimes and Luckey, 1982; Thelin and Heimes, 1987; U.S. Department of Agriculture, 1999). Water-level declines started to occur in the High Plains aquifer soon after the beginning of extensive ground-water irrigation. The water-level declines in the High Plains aquifer occur because of an imbalance between discharge, the largest component of which is ground-water withdrawals for irrigation, and recharge, which is primarily from precipitation. By 1980, water levels in the High Plains aquifer in parts of Texas, Oklahoma, and southwestern Kansas had declined more than 100 feet (Luckey and others, 1981).

Water-level declines may result in increased costs for ground-water withdrawals because of increased pumping lift and decreased well yields. Water-level declines also can affect ground-water availability, surface-water flow, and riparian areas. In response to the water-level declines in the High Plains aquifer, the U.S. Geological Survey, in cooperation with numerous Federal, State, and local water-resource agencies, began monitoring more than 7,000 wells in 1988 to assess the annual water-level change in the aquifer. The purpose of this report is to present water-level changes in the High Plains aquifer from the time prior to substantial ground-water irrigation development (about 1950, which is termed "predevelopment" in this report) to 2002,1980 to 2002, and 2001 to 2002. The water-level measurements used in this report were collected in winter or early spring when irrigation wells generally were not pumping and when water levels generally had recovered from the stress of pumping during the previous irrigation season.

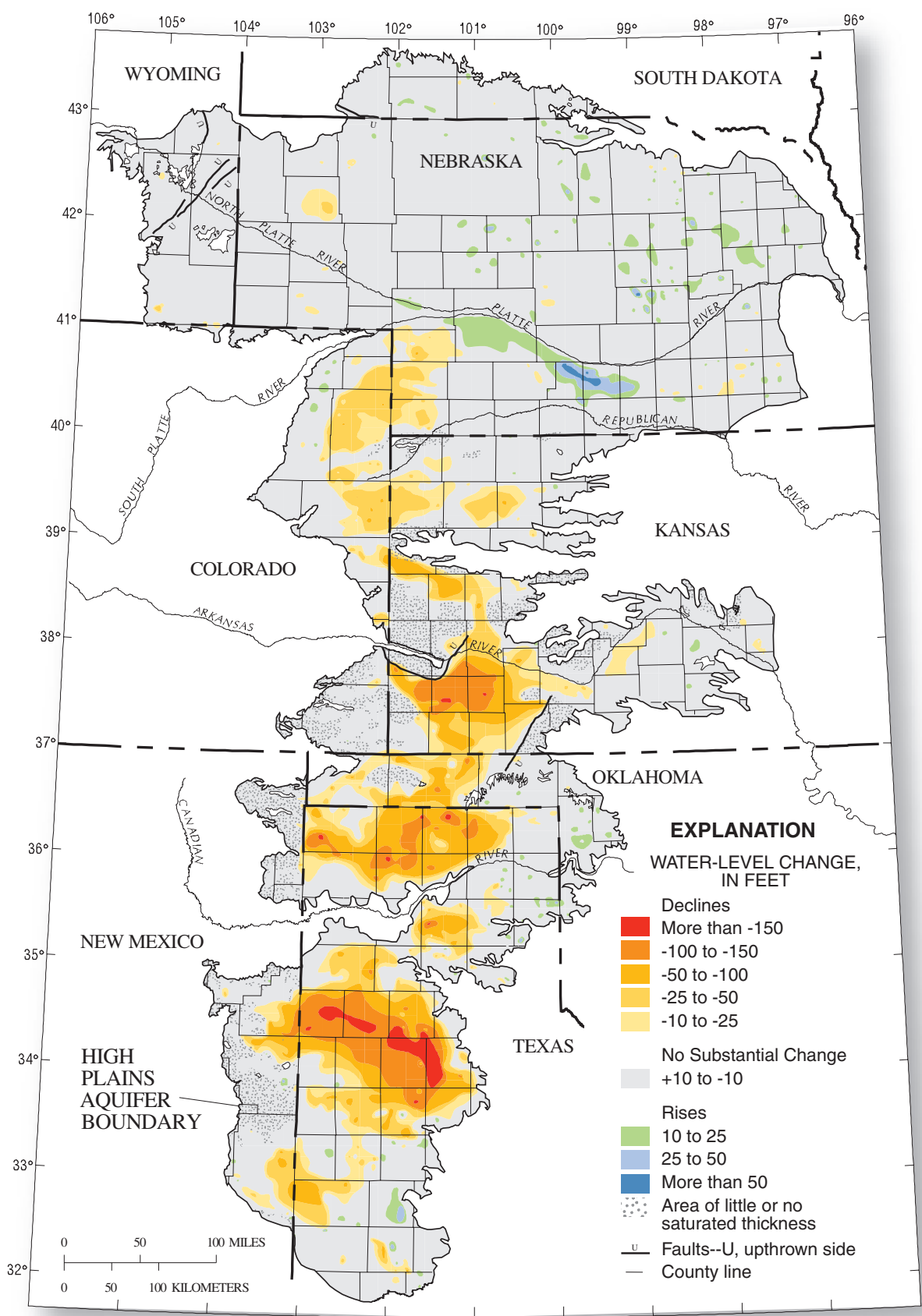

Base from U.S. Geological Survey digital data, 1:2,000,000 Albers Equal-Area projection

Standard parallels $29^{\circ} 30^{\prime}$ and $45^{\circ} 30^{\prime}$, central meridan $-101^{\circ}$

Figure 1. Water-level changes in the High Plains aquifer, predevelopment to 2002 (modified from Luckey and others, 1981 McGuire and others, 2003). 


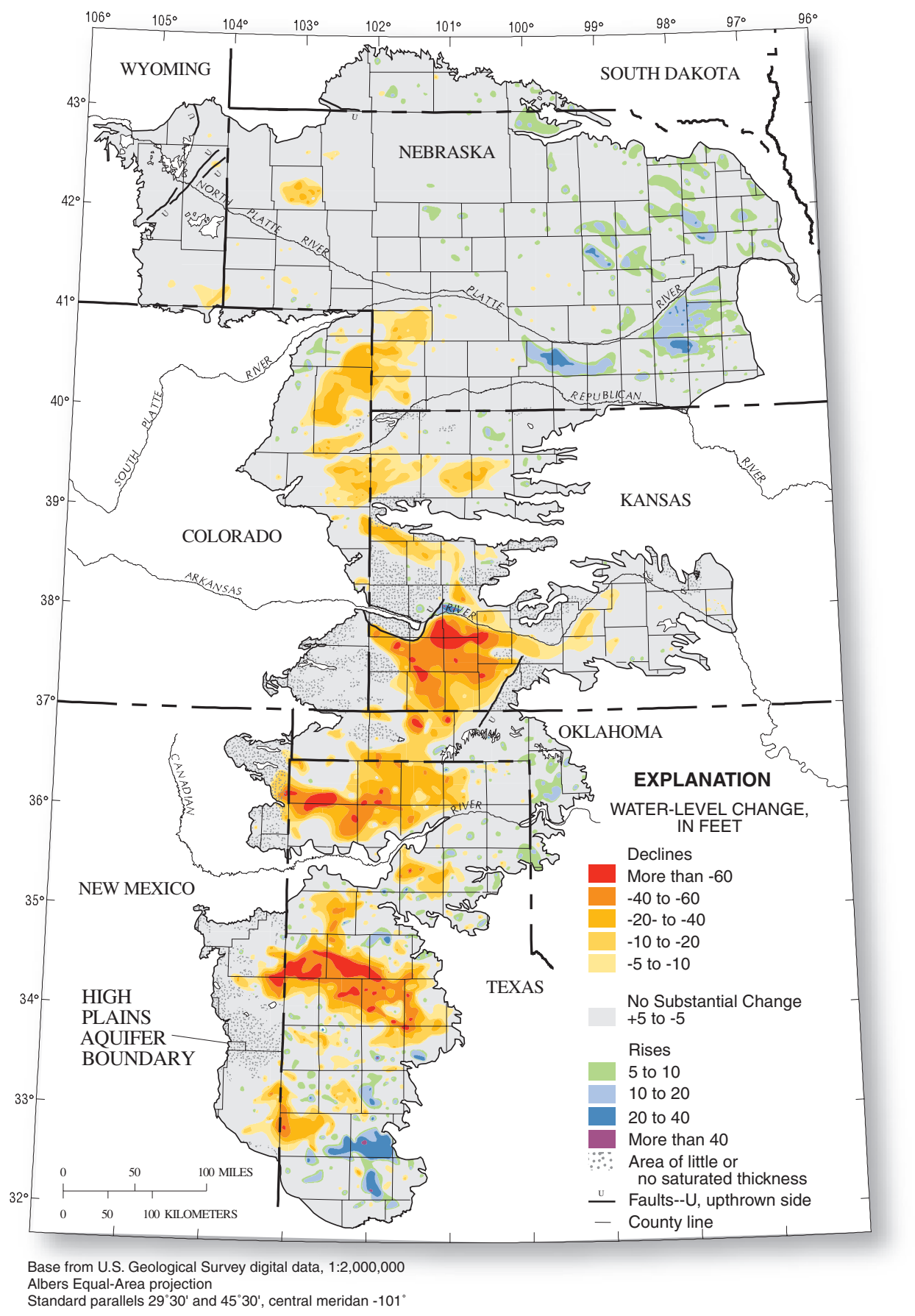

Figure 2. Water-level changes in the High Plains aquifer, 1980 to 2002.

The water-level-change maps and related area-weighted average water-level change values in this report were prepared using two methods. The maps of water-level changes, predevelopment to 2002 (fig. 1) and 1980 to 2002 (fig. 2), show contours of water-level-change ranges, which were drawn manually based on predevelopment, 1980, and 2002 water levels from available wells, contours of water-level changes from previous reports (Luckey and others, 1981; McGuire and others, 2003), and predevelopment and recent water-table maps, if available. The map of generalized water-level changes, 2001 to 2002 (fig. 3), shows computer-generated Thiessen polygons (Thiessen, 1911) colored by the water-level-change range. Thiessen polygons apportion the water-level change in each well to an area around the well; the size of each polygon depends on the proximity of neighboring wells. The predevelopment to 2002 and 1980 to 2002 areaweighted average water-level changes were computed for each comparison period by summing the areas within the manual contours of water-level change multiplied by the value of the mid-point of the contour interval and dividing the result by the total area. The 2001 to 2002 area-weighted average water-level change was computed by summing the area of each Theissen polygon times the actual water-level change value associated with the Theissen polygon and dividing the result by the total area. 


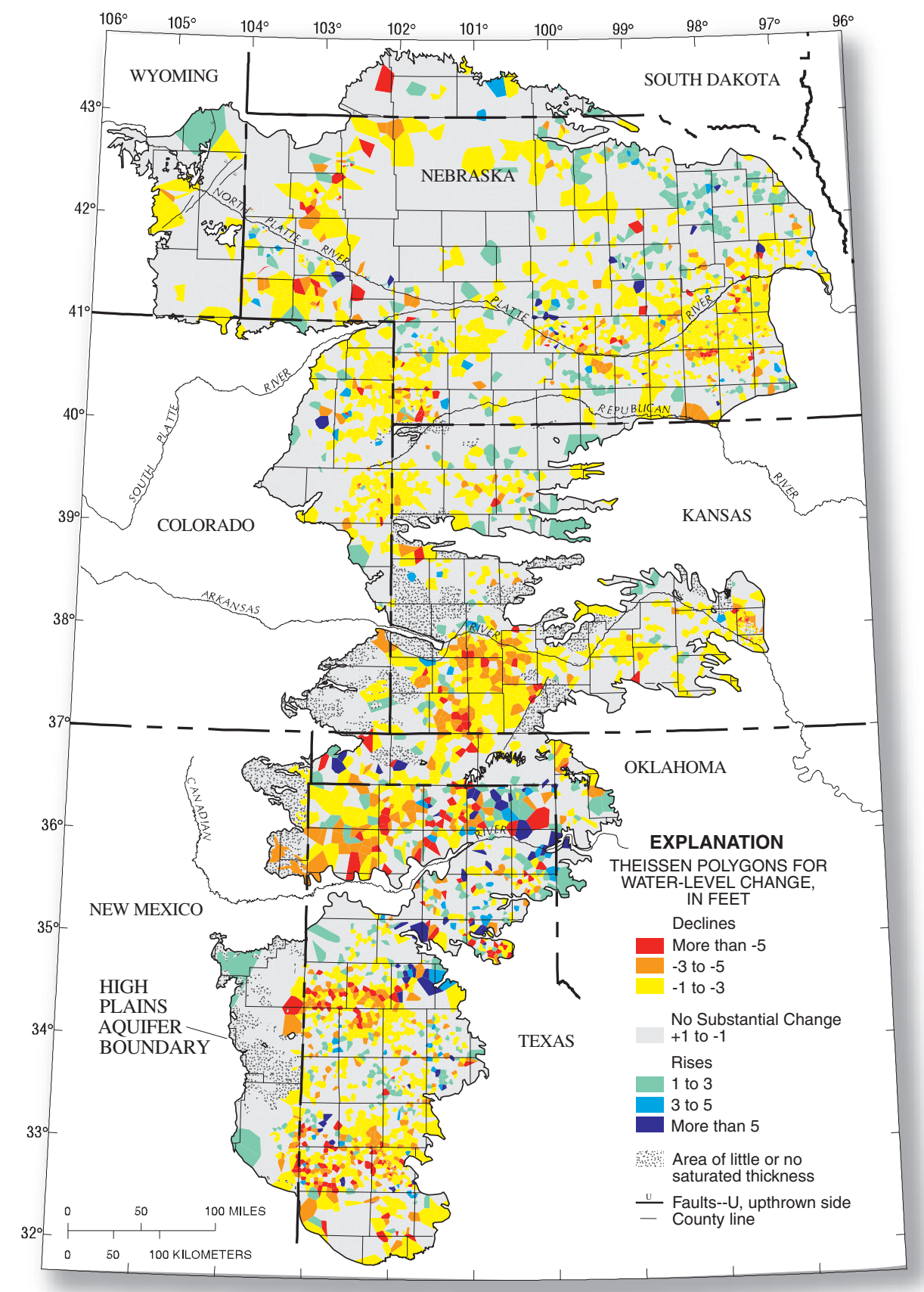

Base from U.S. Geological Survey digital data, 1:2,000,000 Albers Equal-Area projection

Standard parallels $29^{\circ} 30^{\prime}$ and $45^{\circ} 30^{\prime}$, central meridan $-101^{\circ}$

Figure 3. Generalized water-level changes in the High Plains aquifer, 2001 to 2002.

\section{WATER-LEVEL CHANGES, PREDEVELOPMENT TO 2002}

The map of water-level changes in the High Plains aquifer from predevelopment to 2002 (fig. 1) is based on water levels from 3,860 wells (table 1). Ninety-nine percent of water-level changes from predevelopment to 2002 in the 3,860 wells used were between a rise of 39 feet and a decline of 167 feet. The area-weighted average water-level change across the High Plains aquifer, not including the areas with little or no saturated thickness, was a decline of 12.1 feet (table 2). About 24 percent of the aquifer area, not including the areas with little or no saturated thickness, had more than 10 feet of water-level decline from predevelopment to 2002. Large areas with more than 50 feet of water-level decline occurred in southwest Kansas, east-central New Mexico, the central part of the Oklahoma Panhandle, and the western part of the Texas Panhandle.

\section{WATER-LEVEL CHANGES, 1980 T0 2002}

Ninety-nine percent of all water-level changes from 1980 to 2002 in the 4,746 wells used were between a rise of 30 feet and a decline of 81 feet. The area-weighted average water-level change across the High Plains aquifer, not including the areas with little or no saturated thickness, was a decline of 4.0 feet (table 2). About 20 percent of the aquifer area, not 
including the areas with little or no saturated thickness, had more than 5 feet of water-level decline from 1980 to 2002.

Large areas with more than 40 feet of water-level decline occurred in southwest Kansas, east-central New Mexico, the central part of the Oklahoma Panhandle, and the western part of the Texas Panhandle.

\section{WATER-LEVEL CHANGES, 2001 T0 2002}

Ninety-nine percent of water-level changes from 2001 to 2002 in the 7,998 wells used were between a rise of 7 feet and a decline of 9 feet. The area-weighted average water-level change across the High Plains aquifer, not including the areas with little or no saturated thickness, was a decline of 0.6 foot (table 2). Water-level declines occurred over most of the aquifer, excluding the parts of the aquifer with little or no saturated thickness, but water-level rises greater than 3 feet occurred in parts of northeastern Nebraska, the Texas Panhandle, and western Oklahoma (fig. 3).

\section{CHANGE IN WATER IN STORAGE, PREDEVELOPMENT TO 2002}

Because the High Plains aquifer is generally unconfined, the change in water in storage in the High Plains aquifer can be estimated using the water-level change maps (figs. 1, 2, and 3) and the average specific yield of the aquifer in each State (Gutentag and others, 1984). Specific yield is an estimate of the volume of water that a volume of the aquifer will yield by gravity drainage (Lohman, 1979). Total water in storage in the aquifer in 2002 was estimated to be 2,970 million acre-feet. The water in storage declined about 200 million acre-feet from predevelopment to 2002, about 67 million acre-feet from 1980 to 2002, and about 10 million acre-feet from 2001 to 2002 (fig. 4, table 3). This method for calculating the change in water in storage will overestimate the change in storage in local areas if the aquifer reflects confined conditions at the start of the time period and unconfined conditions later.

Table 1. Number of wells measured and used in this report for 2002 water levels and number of wells used for the water-level comparison periods-predevelopment to 2002, 1980 to 2002, and 2001 to 2002.

\begin{tabular}{|c|c|c|c|c|}
\hline \multirow{2}{*}{ State } & \multirow{2}{*}{$\begin{array}{c}\text { Wells } \\
\text { measured } \\
\text { and used in } \\
\text { this report }\end{array}$} & \multicolumn{3}{|c|}{$\begin{array}{l}\text { Wells used in water-level } \\
\text { comparison periods }\end{array}$} \\
\hline & & $\begin{array}{l}\text { Predevelop- } \\
\text { ment to } 2002\end{array}$ & $\begin{array}{c}1980 \text { to } \\
2002\end{array}$ & $\begin{array}{c}2001 \text { to } \\
2002\end{array}$ \\
\hline Colorado & 548 & 394 & 460 & 531 \\
\hline Kansas & 1,396 & 606 & 764 & 1,269 \\
\hline Nebraska & 3,726 & 1,538 & 1,697 & 3,489 \\
\hline New Mexico & 206 & $208^{*}$ & $169^{*}$ & 93 \\
\hline Oklahoma & 304 & 191 & 150 & 220 \\
\hline South Dakota & 116 & 72 & 73 & 113 \\
\hline Texas & 2,888 & 834 & 1,417 & 2,230 \\
\hline Wyoming & 55 & 17 & 16 & 53 \\
\hline High Plains (Total) & 9,239 & 3,860 & 4,746 & 7,998 \\
\hline
\end{tabular}

*Includes 1998 to 2001 water levels, instead of 2002 water levels, for 143 wells in the predevelopment to 2002 comparison period and 66 wells in the 1980 to 2002 comparison period because many wells in New Mexico are measured on a 5-year schedule.
Table 2. Area-weighted average water-level changes in the High Plains aquifer, not including the areas of little or no saturated thickness-predevelopment to 2002, 1980 to 2002, 2001 to 2002.

\begin{tabular}{|c|c|c|c|}
\hline \multirow[b]{2}{*}{ State } & \multicolumn{3}{|c|}{$\begin{array}{c}\text { Area-weighted average water-level } \\
\text { change }\end{array}$} \\
\hline & $\begin{array}{c}\text { Predevelopment to } \\
2002 \\
\text { (feet) } \\
\end{array}$ & $\begin{array}{c}1980 \text { to } \\
2002 \\
\text { (feet) }\end{array}$ & $\begin{array}{c}2001 \text { to } \\
2002 \\
\text { (feet) } \\
\end{array}$ \\
\hline Colorado & -9.5 & -5.1 & -0.6 \\
\hline Kansas & -18.3 & -9.1 & -0.8 \\
\hline Nebraska & 0.2 & 0.6 & -0.5 \\
\hline New Mexico & -14.5 & -5.5 & -0.7 \\
\hline Oklahoma & -13.2 & -4.0 & -0.3 \\
\hline South Dakota & 0.2 & 0.3 & -0.2 \\
\hline Texas & -34.7 & -9.6 & -0.8 \\
\hline Wyoming & -0.2 & -0.3 & -0.3 \\
\hline High Plains (Total) & -12.1 & -4.0 & -0.6 \\
\hline
\end{tabular}

Table 3. Change in water in storage in the High Plains aquifer, predevelopment to 2002, 1980 to 2002, 2001 to 2002.

\begin{tabular}{|c|c|c|c|}
\hline \multirow[b]{2}{*}{ State } & \multicolumn{3}{|c|}{ Change in water in storage } \\
\hline & $\begin{array}{l}\text { Predevelopment to } \\
2002 \\
\text { (million } \\
\text { acre-feet) }\end{array}$ & $\begin{array}{c}1980 \text { to } \\
2002 \\
\text { (million } \\
\text { acre-feet) }\end{array}$ & $\begin{array}{c}2001 \text { to } \\
2002 \\
\text { (million } \\
\text { acre-feet) }\end{array}$ \\
\hline Colorado & -11.1 & -6.0 & -0.6 \\
\hline Kansas & -47.5 & -23.5 & -2.1 \\
\hline Nebraska & 1.5 & 3.6 & -3.1 \\
\hline New Mexico & -7.9 & -3.0 & -0.4 \\
\hline Oklahoma & -11.0 & -3.3 & -0.3 \\
\hline South Dakota & 0.1 & 0.1 & -0.1 \\
\hline Texas & -124.4 & -34.6 & -3.0 \\
\hline Wyoming & -0.1 & -0.1 & -0.1 \\
\hline High Plains (Total) & -200.4 & -66.8 & -9.7 \\
\hline
\end{tabular}




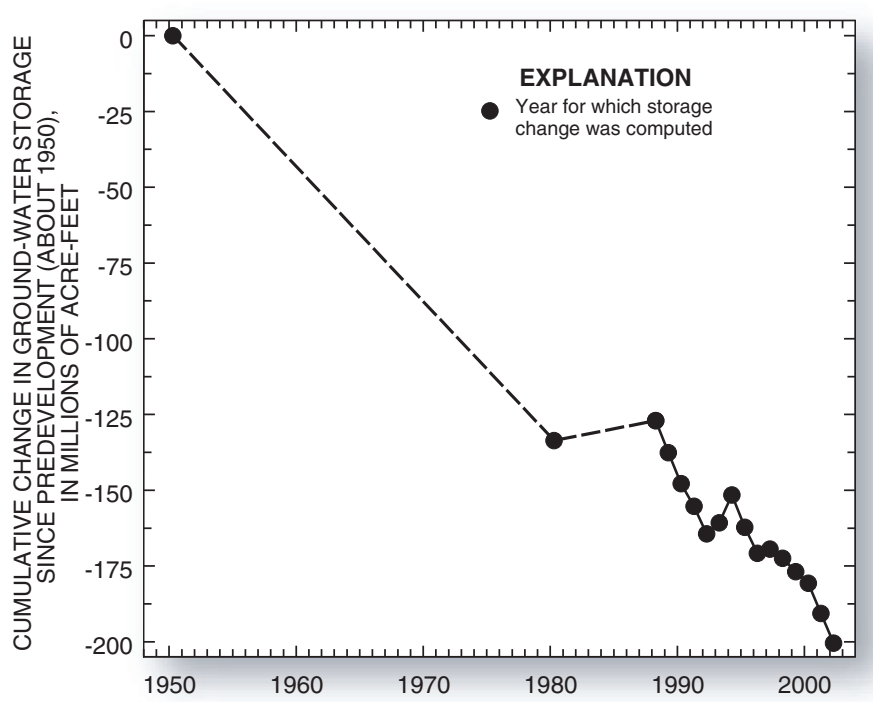

Figure 4. Cumulative change in ground-water storage in the High Plains aquifer since predevelopment (modified from U.S. Geological Survey, 2002).

\section{REFERENCES}

Heimes, F.J., and Luckey, R.R., 1982, Method for estimating irrigation requirements from ground water in the High Plains in parts of Colorado, Kansas, Nebraska, New Mexico, Oklahoma, South Dakota, Texas, and Wyoming: U.S. Geological Survey Water-Resources Investigations Report 82-40, 64 p.

Gutentag, E.D., Heimes, F.J., Krothe, N.C., Luckey, R.R., and Weeks, J.B., 1984, Geohydrology of the High Plains aquifer in parts of Colorado, Kansas, Nebraska, New Mexico, Oklahoma, South Dakota, Texas, and Wyoming: U.S. Geological Survey Professional Paper 1400-B, 63 p.

Lohman, S.W., 1979, Ground-water hydraulics: U.S. Geological Survey Professional Paper 708, 70 p.

Luckey, R.R., Gutentag, E.D., and Weeks, J.B., 1981, Waterlevel and saturated-thickness changes, predevelopment to 1980, in the High Plains aquifer in parts of Colorado, Kansas, Nebraska, New Mexico, Oklahoma, South Dakota, Texas, and Wyoming: U.S. Geological Survey Hydrologic Investigations Atlas HA-652, 2 sheets, scale 1:2,500,000.

McGuire, V.L., Johnson, M.R., Schieffer, R.L., Stanton, J.S., Sebree, S.K., and Verstraeten, I.M., 2003, Water in storage and approaches to ground-water management, High Plains aquifer, 2000: U.S. Geological Survey Circular 1243, 51 p.

Theissen, A.H., 1911, Precipitation averages for large areas: Monthly Weather Review, v. 39, p. 1082-1084.
Thelin, G.P., and Heimes, F.J., 1987, Mapping irrigated cropland from Landsat data for determination of water use from the High Plains aquifer in parts of Colorado, Kansas, Nebraska, New Mexico, Oklahoma, South Dakota, Texas, and Wyoming: U.S. Geological Survey Professional Paper 1400-C, 38 p.

U.S. Department of Agriculture, 1999, 1997 Census of agriculture geographic area series: National Agricultural Statistics Service CD-ROM AC97-CD-VOL1-1B.

U.S. Geological Survey, 2002, Concepts for national assessment of water availability and use: U.S. Geological Survey Circular $1223,34 \mathrm{p}$.

For additional information contact:

U.S. Geological Survey

Federal BIdg., Room 406

100 Centennial Mall North

Lincoln, NE 68508

(402) 437-5082

USGS Nebraska District home page: http://ne.water.usgs.gov 


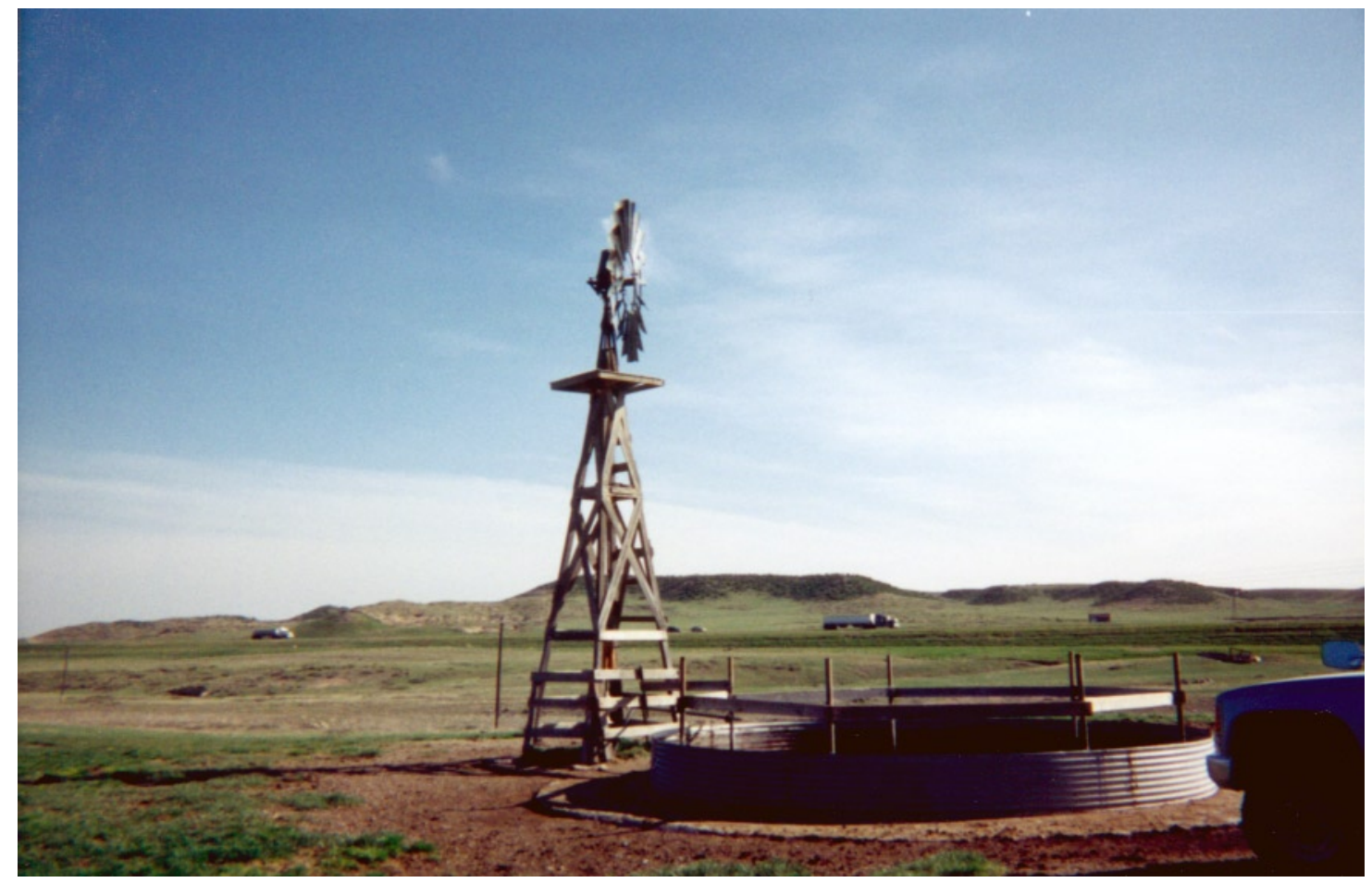

Wind-powered well and livestock watering tank in Platte County, Wyoming (Photograph courtesy of J.P. Mason, U.S. Geological Survey.)

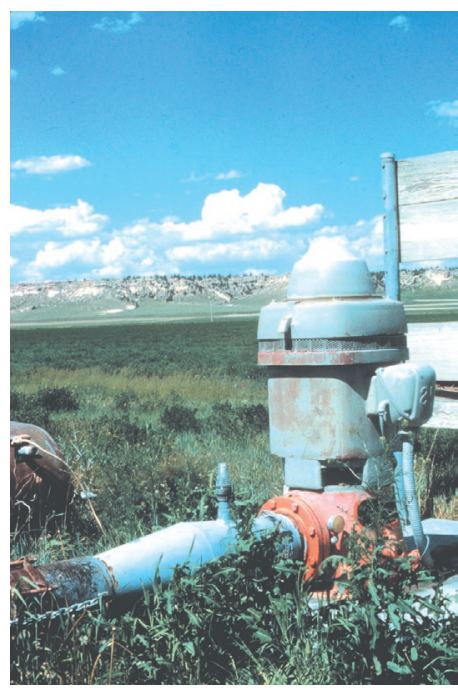

Irrigation well in Laramie County, Wyoming (Photograph courtesy of R.R. Luckey, U.S. Geological Survey.)

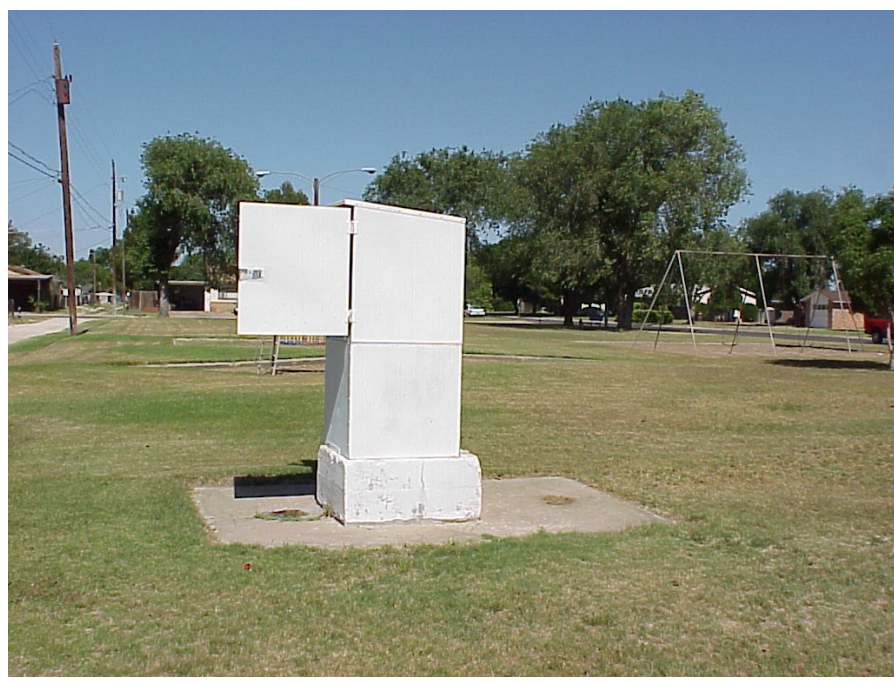

Observation well equipped to measure ground-water levels continually in Lea County, New Mexico (Photograph courtesy of R.R.Cruz, U.S. Geological Survey.) 